\title{
THE ANATOMY OF RIGHTS-BASED VIOLENCE
}

It has been a philosophical tendency for perhaps the greatest portion of the twentieth century to conceive violence, in large part, as a structural phenomenon. The reference to structure is not intended merely to attribute violence to actually existing socio-economic institutions and divisions, nor to protest the silent, stuctural violence they do to those who have been dehumanized by poverty, insecurity, racial and gender exploitation, exploitative economic and labor practices, etc., and who, having been dehumanized, become agents of violence themselves. Rather, the reference is to the conceptual structures that make actually existing institutions and the violence they invoke appear to be rational preconditions for the protection and preservation of rights.

The conceptual culprit to which much modem violence is attributed is the westem liberal-rights tradition itself. It is, according to the critique, a conceptual tradition that has provided us with the vocabulary that permits us to conceive violence as morally legitimized by the rights it claims to serve. All human beings act unavoidably from a sense of their inalienable, i.e. natural, rights, according to the earliest authors of the liberal rights tradition. Rights function as blameless principles of natural self-interest.

The logic of the modern liberal-rights tradition goes beyond the crude association of self-interest and inalienable rights. Respect for one's inalienable rights and liberties is presented as the fundamental prerequisite of human dignity itself. Anything done in the interest of protecting and preserving human dignity is, in effect, self-justifying. The end result is that employment of the logic of rights by any person--natural, artificial, corporate, or whatever-cannot help but lead rather easily to the conceptual legitimization of violence, to what $I$ have referred to in the title of this essay as rights-based violence.

In its more subtle forms, the emphasis on individual rights and liberties has manifested itself, according to its more recent detractors, in the defence of priviledges and, for those who would challenge social and political structures that legitimize priviledges, has manifested itself in various forms of nonrecognition, critically 
referred to as the violence of objectification' or the violence of indifference. In business and economics, for example, the objectifying relations of liberal-rights produce a competitive market place that takes no regard of human need except for the potential markets and possibility of profits that need creates.

The conclusion drawn by the critics of the liberal-rights tradition has been that there can be no solution to the problems of violence that does not penetrate to, and modify or reform these decper conceptual substructures. The priority of individual rights implicit in the westem liberal-rights tradition--sometimes referred to as the metaphysics of individualism--must be overcome, they say. Or, if we are to continue speaking of individual rights, our understanding of rights must be elevated to the point where individual rights dissolve themselves into what we call "human rights," i.e. into rights that imply mutual recognition and respect. What is needed, from the viewpoint of this critique, is an understanding of the relationship of man to man that permits the possibility of living together in "coexistent freedom, where the satisfaction of one person's rights does not have to come at the expense of another person's rights." [10] It is to promote a system of rights in which, in the words of Maurice Merleau-Ponty, "the recognition of man by man" becomes a moral priority. ${ }^{2}$

There is good reason for quoting Merleau-Ponty on this issue. There has been no more fervent champion of this critique of the liberal-rights tradition. In his Humanism and Terror (1947), Merleau-Ponty argued how, in the name of individual rights and liberty, we have legitimized repression and exploitation. The principles of classical liberalism, he argued, have been exhalted

'Susanne Kappeler, The Will to Violence (New York and London: Teachers College Press, 1995), p. 176.

'Merleau-Ponty, Maurice, Humanism and Terror (Boston: Bcacon Press, 1969), p. 15.5. Merieau-Ponty's views are ochood by John D. Caputo's commentary on a Roundtable discussion with Jacques Derrida recently at Villanova University. Defending the responsibility of Derridean doconstruction, Caputo argued "rights come after responsibility." He describes a new Enlightenment which puts "responsibility (to the other) before rights (of the self)." (p. 52) "...for rights are rootod in responsibility." (p. 54) Cf. Deconsinuction in a Nutshell: A Comversation with Derrida, od. with commentary by John D. Caputo (New York: Fordham University Press, 1997). pp. $50,52,53,54$. 
more than the individuals they were intended to serve. "[L]iberty becomes a false ensign-a 'solemn complement' of violence-as soon as it becomes only an idea and we begin to defend liberty instead of free men." ${ }^{3}$ Nothing illustrated this connection between violence and the principles of rights and liberties more dramatically for Merleau-Ponty than the fact that "liberal principles of respect for law and liberty are used to justify strike-breaking in the USA." ${ }^{4}$

What makes the violence legitimized by the liberal-rights tradition so intractable, according to Merleau-Ponty, is its reinforcement by the deeper, more fundamental fact that its principles are held to be self-evidently true and inviolable. On this the liberal-rights tradition allows no flexibility. The condemnable result, Merleau-Ponty explains, is that violence "in the guise of liberal principles" ${ }^{\prime \prime}$ is invoked to guarantee the interests of those whom those principles have come to serve. The westem liberal-rights tradition is conceptually unable to accommodate the "alterity" demanded by contemporary moral consciousness, i.e., the equal reasonableness of essentially other, radically different political principles, principles that would produce altogether different forms of political existence. The liberal-rights tradition, Merleau-Ponty argues, is unable to acknowledge the dogmatic character of its own assumption that "legitimate diversity of opinions' always presupposes a fundamental agreement and is only possible on the basis of an unchallenged premise." ${ }^{16}$ It is, Merleau-Ponty says, "the dogmatic ground of liberalism, (that) it can only guarantee certain freedoms by taking away the liberty to choose against it." That is, the liberal-rights tradition assumes that there is a basic moral and political neutrality to the dogma of individual rights, that there is no prejudice involved in insisting that all criticism of social and political conditions and institutions be expressed in the terminology of liberal rights, and that the mctaphysics of individualism at the heart of liberal-rights theory is

\footnotetext{
'Mcrlcau-Ponty, p. xxiv

thid., p. 67.

'Ihid., p. xiii

"Ihid., p. 67.
} 
morally unprejudicial. Recognition of individual rights is considered the metaphysical a priori of all moral and political judgment. Those who would resist it are dismissed as irrational.

The liberal-rights tradition cannot tolerate conceptually a rejection of the principles of that tradition; it cannot accommodate radical "alterity" without abandoning its commitment to those liberal-rights.

While it can accommodate the criticisms of those who would object that their rights have been violated (even systematically violated), it cannot accommodate revolutionary action that would overthrow the principles of the liberal-rights tradition themselves.

Transcending the classical rights-based legitimization of violence requires, according to Merleau-Ponty, nothing less than "the recognition of man by man" ${ }^{77}$ He means, as I understand him, the creation of social and political structures that promote mutual recognition rather than mutual opposition, peaceful coexistence rather than the violence of objectification.

It is useless to dispute the legitimacy of the critique as it has been stated above, though the inability to tolerate "alterity" may be more a truth about political existence per se than a failure specific to the liberal-rights tradition.. Nevertheless, examples of violence legitimized legally and morally by liberal-rights principles are far too numerous to deny the connection. I would suggest, however, that regardless how justified are the criticisms of those who oppose the principles of political-liberalism, and regardless of how well-intended they may be, their revolutionary recommendations for change do not point the way to a remedy to violence, but only to its transformation. Attempts to remedy the problem of violence that proceed by calling for structural changes, i.e. structures that no longer include the premises of metaphysical individualism and individual rights, that aim, rather, at producing "recognition of man by man," I would argue, too easily issue in new forms of violence that are often conceptually invisible to those who argue for them. In fact, these newer structures of violence ironically appear to many people to be the basis of a more peaceful relationship of man to man simply because they are repudiations of the older structures of violence deriving from the liberal-rights tradition. They remain, nevertheless, within the horizon of liberal-rights theory, subject to

'shed., p. 155. 
versions of the same critique. That comes out most clearly when one follows out the philosophical evolution of rights theory, from its origins in the seventeenth century to the present, and one is able to see how the concept of individual rights has transformed itself into something very different, something that serves today as the basis of the current critique of the liberal-rights, still susceptible, nonetheless, in slightly revised ways, to its own critique.

The Philosophical Evolution of Violence in Liberal Rights Theory

The idea of individual rights emerged originally in the seventeenth century, in the philosophy of Thomas Hobbes as little more than an expression of the survival impulse. All living beings, he argued, exhibit an irresistible, natural desire to secure their survival. It is an impulse, Hobbes said, that is "found even in the embryo." ${ }^{88}$ That is to say, it is not a learmed behavioural response generated in human beings by the social and political structures to which they submit themselves. New and different social and political institutions may change the social contours of this natural desire, but they cannot eradicate it. The irrepressible character of the desire for survival, coupled with the unavoidable realization that survival depends on acquisition of power, creates in each and every person a "perpetual and restless desire of power after power that ceases only in death."

This, according to Hobbes, was man's natural condition. The Hobbesian natural condition referred not, as, say, for Rousseau, to some prehistoric situation that existed before the time that man acquired the arts, the art of sociability in particular, but, rather, a permanent political possibility; it referred to the insecurity that exists whenever there exists no political authority to guarantee one's security. It could refer to the situation that exists during one's walk in a dark and lonely city park at 2:00 a.m. At such times, and in such situations, it is reasonable (natural) and blameless for people

'Hobbes, De Corpore, in The English Works of Thomas Hobbes (London: John Bohn, 1839, Germany: Scientia Verlay Aalen, 1966, reprint), vol. III, ch. 25, art. 12 , p. 407.

${ }^{\circ}$ Hobbes, Leviathan, in The English Works of Thomas Hobbes, vol. III. clupt. xi, pp. 85-6 
to exhibit what, on other occasions, might be considered an excessive concern for their safety and to act accordingly.

In spite of the ugliness in his description of man's natural situation, however, it is wrong to say that Hobbes depicted human nature as evil and inherently violent. The violence that man seems unable to avoid derives from a dilemma he faces. It is, in fact, a dilemma that any person could be forced to confront at almost any time. The dilemma is that no man can avoid a feeling of insecurity. In the absence of genuine knowledge of what precisely is required to assure one's survival, security, and modest wellbeing, Hobbes says, we have a right to whatever we, in our own judgment, believe is necessary for securing our preservation, security and wellbeing. That holds even when we are wrong, since it would be unreasonable in such a situation to expect a person to postpone his or her defensive responses until knowledge is certain, e.g. that the person who has confronted me intends to rob me rather than merely to talk, or to kill me rather than merely to rob. The unavoidable magnification of natural self-interest explains why birds and squirrels fly or nun away when one comes upon them in a park or a yard, why it is natural and right for them to do so, even though those from whom they run intend them no harm. The birds and the squirrels cannot be sure of that, and they assure their survival best when they act on their fears, whether their fears are knowledgable or not. In much the same manner, Hobbes argued, man's beliefs, interests and his rights are informed and defined by his fears, and one's fears are limited only by the power of his imagination. In fact, every imaginable threat to one's life is something to fear and, hence, something against which one has a right to defend himseif. That means that it is reasonable for one to do so. Furthermore, it is conspicuously obvious (to Hobbes) that there is nothing so remote that one could not imagine a situation where it would constitute a conceivable threat to one's survival. All that is needed to create this unfortuate insecurity is the possibility that just one human being would have some such capacity for suspecting the intentions of others, constituting for others thereby the possible threat (e.g. the threat of a preemptive "response") which necessitates their defensive response. The almost limitless character of the human imagination exposes thereby a whole series of potential threats, defining at the same time a whole series of justifiable responses, i.e. justifiable violence. The situation creates a condition in which 
every person can be said, according to Hobbes, to have a right to to absolutely everything whatsoever, a right, even, to every other person's body.

Unmediated natural rights (those rights one must defend by himself) become a recipe for and justification of unlimited violence whenever and wherever there is no sovereign authority, and one finds himself in a situation where he must serve as the sole guarantor of his own security.

This does not mean, for Hobbes, that human beings are irrational or that they are acting irrationally when they commit acts of violence. On the contrary, violence in such situations is perfectly reasonable. That, in fact, is the heart of the problem as Hobbes sees it, and is also the heart of the Western rights-dilemma. The dilemma is magnified by the fact that the unmediated effort of any individual to secure his or her own natural right is doomed to betray itself. In the unmediated natural condition, individuals learn to anticipate threats against their well-being, including merely potential threats posed by others whose true intentions may or may not be malevolent. One never knows for sure. Consequently, it is reasonable (prudent, or natural) to suspect others of having concealed hostile intentions on which they will act whenever they believe it is to their advantage to do so. That also makes it reasonable for one to prepare oneself by acquiring enough power to make oneself invulnerable. So, otherwise peaceful people buy handguns for their homes, locks and special alarms for their cars, etc. Such preemptive behaviour makes it reasonable (prudent, or natural) for others to reciprocate. They, following the same logic of rights, realize that they have to anticipate the threat one now poses for them, especially when they observe one suspiciously augmenting his powers. So, one's efforts to defend oneself against threats-real or imagined--to one's welfare inadvertently invokes those very same threats. This is the dilemma that leads Hobbes to conclude that "nature dissociates," and to claim that the state of nature cannot help but collapse into a condition of unending violence.

Hobbes gave us a compelling account of the self-vitiating consequences that follow from acting on the logic of natural self intcrest. The problem, as he presents it, is epistemological, since

\footnotetext{
"Hobbes, I eviathan, chapt. xiv, p. 117.
} 
insccurity is maximized by one's ignorance of the intentions of others, one's future needs, unforesecable crises, etc. It shows how the logic of unmediated natural right has the inherently contradictory character of negating itself through the simple agency of asserting itself. The only solution Hobbes could find to the dilemma-the dilemma that arises whenever violence becomes reasonable-was to invoke an irresistible power, a sovereign who would act, in effect, as a principle of knowledge for each individual bearer of rights. A sovereign with absolute power could use that power (and would use it, since it would be in his natural self-interest to do so) to keep his subjects from doing violence to each other by assuring each of them that no malevolent intentions will be tolerated. The threats implicit in sovereign power would enable his subjects to know with certainty that they are safe from the predations of others, since no one would willingly bring sovereign power down upon himself.

Hobbes' answer to the problem of violence solved one problem, it seemed, by creating another. Peace and security depend on the existence of a sovereign with absolute power and authority, meaning by that, a sovereign who retains all the rights of nature and, with them, all the justifications for violence that the appeal to natural rights provides. The problem for subsequent philosophers in the liberal-rights tradition was to save us from such solutions, i.e. from rights-based abuse of sovereign authority. What was needed was another more sociable way of conceiving the mediation of rights that simultaneously (1) avoided the reasonableness of violence and (2) cscaped the need for submission to a sovereign with absolute power.

According to C. B. Macpherson in his work, The Political Theory of Possessive Individualism, the possibility of just such mediations would exist in "some kind of society which provides peaceful, non-violent ways by which every man can constantly seek power over others without destroying the society." "11 Macpherson called it the "possessive market society." ${ }^{12}$ He was referring to the capitalistic system of production and exchange. Macpherson

"C. B. Macpherson: The Polifical Theory of Possiessive Individualism (London: Oxford University Press, 1962), p. 46.

${ }^{12}$ bid. 
sociable way of conceiving the mediation of rights that simultaneously (1) avoided the reasonableness of violence and (2) escaped the need for submission to a sovereign with absolute power.

According to C. B. Macpherson in his work, The Political Theory of Possessive Individualism, the possibility of just such mediations would exist in "some kind of society which provides peaceful, non-violent ways by which every man can constantly seek power over others without destroying the society." "1" Macpherson called it the "possessive market society." ${ }^{12}$ He was referring to the capitalistic system of production and exchange. Macpherson claimed that this social order already existed embryonically in Hobbes time, and Hobbes description of natural man was nothing more than a description of the behaviour of people in this society. It was a society transformed into "a series of competitive relations between naturally dissociated and independently self-moving individuals, with no natural order of subordination." 13 Macpherson's analysis contains within it a more scholarly version of the famous claim made by Pierre Joseph Proudhoun: "la propriété c'est le vol."

Macpherson overstated his claim somewhat in Hobbes case (Hobbes philosophy is grounded upon his physics), but not necessarily for Hobbes successor, John Locke. Locke augmented Hobbes concept of rights, adding to it a reflexivity that made it appear more perfectly suitable as the foundation of the structural violence in what Macpherson referred to as the "possessive market society." All rights, Locke argued, come about through one's investment of his labor in things. Every person has a natural right to life, not as an expression of his irrepressible desire for survival, but, rather, because he has natural ownership of himself. Rational beings own and impute to themselves their own actions, raising themselves thereby from the status of mere natural beings to the status of persons with

"C. B. Macpherson: The Political Theory of Possessive Individualism (London: Oxford University Press, 1962), p. 46.

"Ihid.

"Macpherson, p. 17 
rights. Rights are now anchored not in nature, but in structures of consciousness. This is a new idea, and a rather strange one at that. Locke's theory makes one's right to life a property right. One owns all his own possessions and his own self as well. One's life is one's property.

If it is true, as Locke declared, that all one's rights come about through an investment of labor, it must follow that one's right to life (ownership of himself) had to have come about through an act of labor on himself. This is what Locke appears to have argued in the second edition (1694) of his Essay Concerning Human Understanding. ${ }^{\text {is }}$ By what one might call the "labor of consciousness" is" exercised on himself, one acknowledges his actions (past and future) as his own. And so, Locke concluded. "Every man has a property in his own person; this nobody has any right to but himself." ${ }^{16}$ This had the important side-effect of generating the foundations for natural responsibility at the same time that it produced the foundations of natural right.

One important implication that follows from Locke's modification of Hobbesian natural right is that those beings that exhibit no evidence of self-ownership (those who acknowledge no responsibility for their actions) have no rights. Animals, for example, show no evidence of guilt, no sense of responsibility for what they do. Hence, they give no evidence of ownership of their own actions. The killing of an animal, consequently, is to

\footnotetext{
14.". This personality extends itself beyond present existence to what is past. only by consciousness--wherchy it becomes concerned and accountable; owns and imputes to itself past actions . . . All which is founded in a concern for happiness, the unavoidable concomitant of consciousness. . ." John Locke. Esiscey ('incerning Human Understanding. (New York: Dover Publications, Inc.. 1959), vol. I Book II. chapter xxvii, (p. 467).

"Herber, Gary, "John Locke: Natural Rights and Natural Duties," Juhrhuch fiur Reche und Eillik. Band 4 (1996), p. 604; and Herhert. (jary. "The Labor of Consciousness and the Worlding of Right in Ilobhes and locke," The Americun (atherlic Philessophical Qhuarcterly, vol. I,XIV. 1990.

"I cocke, John. Secomd Treurise of (iovernment, (Indianapolis and New York: The litobbs-Merrill (company, Inc., 1952). paragraph 27. p. 17.
} 
He writes, "This makes it lawful for a man to kill a thief who has not in the least hurt him, nor declared any design upon his life farther than, by the use of force, so to get him in his power and to take away his money, or what pleases him." This follows, Locke claims, because, "I have no reason to suppose that he who would take away my liberty would not, when he had me in his power, take away everything else."

The somewhat different concepts of natural right we find in the philosophies of Hobbes and Locke served in various ways as the philosophical foundations of the British and American revolutions, and their terminology was immortalized in the United States Declaration of Independence. Civil rights for both Hobbes and Locke were never more than the politically mediated form acquired by natural rights as man enters into civil association. A civil society constructed on such conceptual foundations will, no doubt, encourage all the forms of violence that those foundations legitimize.

Historically, the philosophical critique of and corrective to rights-inspired violence was proposed jointly by Immanuel Kant and Johann Gottlieb Fichte. Neither Kant nor Fichte disagreed all that much with Thomas Hobbes description of the human situation, with this subtle but important exception: Rather than explain the natural condition in Hobbesian terminology as a situation where rights clash, where one right is satisfied only at the expense of another, they reconceived it as a condition in which there exist no rights whatsoever because no rights are recognized. There are, they argued, no rights where there are no corresponding obligations. The unilateral character that rights had for Hobbes and Locke was abandoned. Eliminating the unilateral character of rights would, presumably, go a long way toward creating a political situation in which acts of violence would be unthinkable. Rights could not rightfully clash; there would be no rights without there also being corresponding obligations to respect those rights, and no rights which would justify preemptive violence against another person.

Kant defined a right as "the capacity for putting others under obligation." ${ }^{18}$ According to Kant, rights exist only to the extent that

\footnotetext{
"Locke, Second Treatise, paragraph 18, p. 12.

IXImmanucl Kant, The Metaphysics of Morals, translation, Mary Grcgor
} 
they are sustained by the obligations of others to respect those rights. That means, there can be no rights outside a condition of social harmony within which the assumption of an obligation is practically possible.

The conceptual anchor of Kant's revised theory of rights is the idea that a right is the capacity to obligate another. That means that one's own rights depend on the other's capacity to be obligated. According to Kant, the other cannot be obligated unless he is free, autonomous. Kant adopted John Locke's terminology to explain the situation: one must be able to impute to himself his own actions. Those who exhibit this ability are more than man (the human animal); they are persons.. As Kant explains it,

A person is a subject whose actions can be imputed to him. Moral personality is therefore nothing other than the freedom of a rational being under moral laws (whereas psychological personality is merely the capacity for being conscious of one's identity in different conditions of one's existence). From this it follows that a person is subject to no other laws than those he gives to himseif (either alone or at least along with others). A thing is that to which nothing can be imputed. ${ }^{19}$

Autonomous beings can be obligated because they accept ownership of their own actions; things cannot. It is not simply that their actions can be traced to them as their cause; their actions are the results of their own autonomous choices. The connection between rights, freedom and obligation is explained by Kant in this way.

We know our own freedom (from which all moral laws and so all rights as well as duties proceed) only through the moral imperative which is a proposition commanding duty, from which the capacity for putting others under obligation, that is, the concept of a right, can afterward be

(New York: Cambridge Universil, Press, 1991), p. 64.

${ }^{19} \mathrm{Kanh}$ The Metaphysics of Morals, p. 50. 


\section{explicated. ${ }^{20}$}

Autonomous beings, beings who impute their own actions to themselves, can be obligated. The question is: What can invoke their obligation? Kant's answer is, only another free being. No person can be obligated by mere things. Here, a problem emerges for Kant. He acknowledges, in agreement with Thomas Hobbes, that man is not truly able to act entirely without regard for his natural inclinations in perfect accord with the moral law. A perfectly free, i.e. good, will, it seems, is not a practical possibility for man, or for any being other than a divine or holy will. ${ }^{21}$ Admittedly, man is something more than a mere beast, insofar as he is not totally controlled by sensible impulses. That, for Kant, is enough. Mutual recognition of rights can be provided for, Kant believed, without relying on the morality of man's inner motives, simply by insisting on the external conformity of his will to the law. Kant explained,

The concept of an external right is derived from the concept of freedom in the extemal relation of human beings to each other ... . Right is the limitation of every man's freedom so that it harmonizes with the freedom of every other man in so far as harmonization is possible according to a general law. ${ }^{22}$

All rights arise through mutually sustaining acts of recognition through which each perceives the other externally as an independent will whose actions can be imputed to him or her. They are the measurements of external freedom only, meaning by that freedom only in one's relationship to others, freedom from hindrances. Universally enjoyed extemal freedom-what Kant calls coexistent freedom-and, therefore, the existence of rights, has its

"Kant, The Melaphysics of Morals, p. 64

${ }^{21}$ Kant, The Metaphysics of Morals, p. 42

"Kant, "Thoory and Practice Concerning the Common Saying: This May be True in Thoory But Does Not Apply to Practicc," in The Philosophy of Kant (New York: Modem Library, 1949), p. 415. 
precondition in reciprocity of recognition. Free persons mutually recognize and respect each other's rights.

One's capacity to obligate another (and, by implication, one's own rights) depends, consequently, on one's capacity to reveal oneself to the other as a free being, one who imputes his actions to himself. One can do that only by doing what no mere thing can do-i.e. by acknowledging the other as a free being, as a person having rights through the simple agency of respecting all that he claims as his, i.e. by restricting oneself. By acknowedging the other's freedom, Kant seems to say, one creates the grounding preconditions of one's own rights. At the same time, one acknowledges the other as a morally free being (a person) to whom obligations are due, meaning by that, one who must not be treated as (or reduced to the status of) a mere thing to be used for one's own advantage (since the objectification of the other transforms him into a being one cannot obligate, thereby eradicating the possibility of one's own rights). All rights, then, are entirely dependent upon the reciprocally sustaining extemal relationship of will to will in which each externally recognizes (or acknowledges) the other as internally free.

Fichte, who makes much the same analysis of rights, says one must "manifest free activity," ${ }^{23}$ that is, one must voluntarily restrict oneself. One who manifests free activity does so by respecting the other's property. The act of voluntarily restricting oneself-something no animal ever does-reveals one to the other as an autonomous being, a person, one who is capable of being obligated. The other can obligate one in fact, of course, only by reciprocating, that is, by manifesting free activity as well, by voluntarily restricting himself. The result is, conceptually at least, a reciprocally generated set of rights and obligations. Fichte writes,

The mutual cognition of individuals is conditioned by this, that each treat the other as free, (or, restrict his freedom through the conception of the freedom of the other.) ... The relation of free beings toward each other is therefore the relation of a reciprocal causality upon

${ }^{23} \mathrm{~J}$. G. Fichte. The Science of Rights, translated A. E. Krocger (London: Roullodge \& Kegan Paul, 1970), pp. 65-66. 
each other through intelligence and freedom. No free being can recognize the other as such, unless both mutually thus recognize each other; and no one can treat the other as a free being, unless both mutually thus treat each other.

The conception, here established, is very important for our purpose; for it is the basis of our whole theory of Rights. ${ }^{24}$

Or course, the contrary also holds. If one does not recognize the other as a morally free being (if one uses the other for one's own purposes, especially if one threatens him with violence), one destroys the politically practical possibility of his being a moral person. His capacity for being free is obstructed by his irrepressible fear for his life. Having been used and thereby reduced to a mere thing, the other will have been released from having obligations. Having been released from his obligations, one destroys the grounding precondition of one's own rights. This amounts to a reestablishment of the conditions of mutual violence. It led Kant to conclude, "Freedom (independence from being constrained by another's choice), insofar as it can coexist with the freedom of every other in accordance with a universal law, is the only original right belonging to every man by virtue of his humanity."

For both Kant and Fichte, the implication of this analysis of rights is that freedom, peace, and the possession of rights are intelligible only when human beings have formed a community of mutually recognizing, mutually dependent persons. As Fichte says, "Man attains rights only in a community with others as indeed he only becomes a man . . . through intercourse with others. Man, indeed, can not be thought as one individual. ${ }^{.26}$

"Fichte, The Science of Rights, pp. 67-68. "Something bocomes my property only because others renounce their right to it, respocting my desire to koep it for myself. This act of renunciation by all, and this alone, is the basis of my right." Johann Gonticb Fichte. The Closod Commercial State, in The Political Thought of the (ierman Romantics 1793-1815. od. H. S. Reiss (Oxford: Basil Blackwell, 1955), pp. 88-89

${ }^{2 s}$ Kant, The Meraphysics of Morals, p. 63.

${ }^{26}$ Fichte, The Science of Rights, p. 160. "Man bocomas man only amongst men." 
Fichte and Kant believed a whole community of free beings agreeing mutually and voluntarily to restrict their freedoms was a possibility, though there may be no immediately obvious and uncomplicated way for such a community to come into historical being. Certainly, it would be made more likely if a citizenry were to conceive themselves and their interests in Kantian terminology. The adoption of his terminology would make it reasonable-a matter of self-interest-to speak of each citizen's voluntary resolve "never to treat the others as mere things, but always as free beings." 27 Their mutual, voluntary self-restriction would constitute a law of permission ${ }^{28}$ that would leave each person to his own free will, permitting each the free and otherwise unlimited exercise of his rights. By applying the law voluntarily to his own free activity, each becomes a lawful member of the community and yet remains entirely free. This would be a community within which self-interest would prevent any citizen from committing an act of violence on any other citizen. The rights that are created, of course, are, for Kant and Fichte, nothing more than a freedom from interference. For Kant, rights are not the natural extensions of needs, not even critical needs. ${ }^{29}$ One's needs neither give one rights nor do they obligate others.

When Kant and Fichte consider how this reciprocally generated set of rights-this condition of coexistent freedom-could be sustained, the ugly problem originally addressed by Thomas Hobbes retumed. Fichte acknowledged that when left to their own contrivances, individuals inevitably trespass upon one another's rights, if only from carelessness. ${ }^{0}$ Even if people were not careless, the possibility of an uncoerced community is precluded by the fact that, "No one can know the inner sentiments of the other."

(p f()) Cf. also pp. 81-82, p. 170

${ }^{27}$ Fichtc. The Science of Rights, p. 128. Cf. also pp. 131, 161.

${ }^{2 n}$ Fichic, The Sicience of Rights, pp. 22-23, pp. 80-81.

${ }^{29}$ Kant, The Metaphysics of Morals, p. 60.

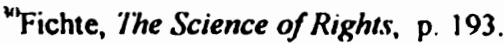

"Fichtc, The Sicience of Rights, p. 148, 145, 191. 
Ignorance of the intentions of others makes Hobbesian suspicion (and, hence, latent warfare) reasonable. The converse is equally true. No one can prove his own sincerity to another, making the other's suspicion of oneself equally reasonable. Both inwardly and outwardly, we remain strangers. Eliminating the unilateral character of rights one finds in the rights theory of Hobbes and Locke and adopting, instead, a concept of rights wherein rights and obligations are correlative does not resolve the problem of rights-based violence so long as mutual recognition is not assurred.

Both Kant and Fichte proposed a way out of this dilemma. Kant explained it by calling upon the notion of "purely intelligible possession." By the mere act of possessing something (purely intelligible possession, "purely intelligible" because one's ownership is not necessarily recognized and respected by anyone else), Kant says, one has already committed himself to a willingness to enter into civil society, that is, to acknowledge reciprocally the rights of others to their possessions. ${ }^{32}$ One has, in principle, chosen for oneself the maxim that every person has a right to those things he has acquired that have not been the prior possession of somebody else. Kant's reasoning is grounded upon the realization that one cannot obligate a mere animal to respect one's possession, and, hence, can have no rights against them. Animals and things cannot be obligated because they do not own their own actions; their behaviour is a mere conduit for natural forces. Therefore, a claim of ownership can meaningfully be made only against another person, one who is capable of acting as a free being. If a person claiming ownership of something uses the other person, thingifies him, he, in effect, reduces the other to the status of a mere thing, thereby releasing him from any obligations and also, coincidentally, negates the grounding preconditions of his own rights. So, one generates his rights, his ownership of property, according to Kant, only through the act by which one recognizes and respects the other's ownership of his possessions as well.

\footnotetext{
${ }^{32}$ "When I doclare (by word or doed), I will that something extemal is to be minc, I thereby deciare that everyone else is under obligation to refrain from using that object of my choice, an obligation no one would have were it not for this act of mine to establish a right. This claim involves, however, acknowlodging that I in turn am under obligation to every other to refrain from using what is extcmally his." The Metaphysics of Morals, p. 77
} 
What follows from the logic of this argument is that, since, by the act of possessing something, people have transcendentally given their consent to the property rights of others, they may be coerced into respecting the property rights of others without violating their autonomy. They would be coerced to do only what they do willingly. Coercion of this sort does not limit a person's freedom, Kant believes, because it brings out the truth of the original willingness that one exhibits when one acquires possessions. The right to resist predations upon one's property implies that one has chosen as his own a maxim that authorizes the same right of resistance for others. A "law of a reciprocal coercion," Kant says, is "necessarily in accord with the freedom of everyone under the principle of universal freedom, ${ }^{33}$ if only because it is the principle or rule implicit in the universal act of consent that transcendentally preconditions any act of original possession. This is why Kant believes it is consistent with the recognition of rights, including the right of consent, to say, "each may impel the other by force to leave this state and enter into a rightful condition." ${ }^{34}$ We are free, in effect, because we have authorized each other's possessions and the existence of a sovereign power to to guarantee those possessions.

As a corrollary to his account of the reciprocal dependency of rights and obligations, Kant maintained that punishment for the violation of one's rights must always take the form of retribution. Kant's idea has been regularly condemned as an advocacy of legitimized violence. Kant did not see it that way. If people are to create a condition of coexistent freedom, everyone must "assert the right of humanity in his own person,"35 which means that one demand from others recognition for oneself as free, as deserving of respect as a human being. One could intelligibly make such demands, of course, only on another free being, i.e. an autonomous being who owns and imputes to himself his own actions. That is to

"3"...cocrcion which constrains everyone to pay his debts can coexist with the froodom of everyonc, including that of debtors, in accordance with a universal cxtemal law. Right and authorization to use cocrcion therefore mean one and the same thing." The Metaphysics of Morals, p. 58

${ }^{34}$ Kant, The Metaphysics of Morals, p. 124.

"Kant, The Metaphysics of Morals, p. 62. 
say, the dignity of the other depends on his being recognized as an autonomous being, the author and owner of his own actions. Retributive punishment represents an acknowledgment of the humanity and the dignity of the other, since it involves a recognition of the other as the owner of his own actions. We do not punish trees, rocks, animals for what they do, since we do not believe they have the capacity to choose their own actions. They are, in their separate ways, mere conduits for causal forces that run through them. Consequently, they lack all possibility of dignity. When it is to our advantage to do so, we use them; and when they are in our way, we merely eliminate them. None of this involves violence.

According to Kant, retributive punishment of a person is not only not a form of legitimized violence; it is its only repudiation. It represents recognition of the fundamental dignity of man. By comparison, the correction and/or rehabilitation of one who has violated the rights of another implies, from that Kantian viewpoint, his reduction to the status of a mere thing needing repair. The autonomy, self-ownership, and responsibility of the miscrent does not come into play. Whether he chooses to be rehabilitated or not is irrelevant. Deterrence, too, is, from Kant's view, a dehumanizing use of the miscreant for the good of the whole. In fact, even good Christian forgiveness is inseparable from one's dehumanization. To forgive is to erase the other's authorship of his own actions. We treat the forgiven as if they had never committed their nefarious decds. All of these notions of punishment are, from the twin viewpoints of Kant and Fichte, institutionalized versions of the violence of objectification. Retributive punishment, punishment that requires of a miscreant that he requite, make restitution to the person or community he has violated to whatever extent he has violated it, recognizes the miscreant as the author and owner of his actions, a free being, one who is thereby a possible possessor of rights, able to obligate others. Hence, rather than being the political legitimization of violence, his punishment preserves and extends his fundamental human dignity.

\section{Post-Kantian Rights-Based Violence}

This conclusion-that retributive punishment alone is consistent with the freedom and dignity of man and that mutual coercion is the necessary means by which it is possible to produce 
coexistent freedom-turned out to be both philosophically unavoidable for Kant and Fichte and too harsh for the contemporary Westem world. From today's perspective, the Kantian and Fichtean logic of rights lends itself too easily to cooptation by repressive governments. These aspects of their rights-theory, at least, have been repudiated.

Nevertheless, inspired by our critique of liberal-rights-based violence, we have refused to abandon entirely the Kantian, Fichtean notion of rights and the correction it supplied. It is almost universally recognized that Kant's philosophy contains an anticipation of the idea of human rights, a pressentiment of what would be required of a world which, as Merleau-Ponty has said, is characterized by the recognition of man by man, and where structural violence has been brought to an end. It is, to be sure, a conception of rights that focuses on human dignity. It is an often repeated, if somewhat maudlin, observation, that respect for the dignity of human life, were it shared by people and governments everywhere, would mark the end of what, in this essay, has been referred to as structural violence.

Even though Kant is usually acknowledged to be the philosophical origin of this sentiment, the commitment to human rights and to respect for the dignity of human life has separated itself dramatically from what Kant considered fundamental to human dignity. We have seen that, for Kant, dignity required politically (i.e. externally--the domain in which alone the concept of rights is relevant) a capacity to function as the author of one's own actions. To the extent that this means that one's dignity and rights depend on one's ability to accept the heavy burden of personal responsibility that belongs to one who owns and imputes to himself his own actions, we resist. The contemporary concern for human dignity no longer makes self-ownership and individual autonomy its precondition. Human beings are rarely thought of as having the kind of individual volition Kant and Fichte required of them. Certainly, those whom we perceive as having been victimized by the objectifying relations of contemporary industrialized society will not be authors of their own actions. Individual autonomy is considered dispensable metaphysical baggage.

Dispensing with the metaphysical baggage, the Kantian concern for moral autonomy, while retaining otherwise Kant's conception of right, has, admittedly, made it possible for us to 
extend the idea of rights to those who are senile or otherwise mentally incapacitated, to fetuses, and even to animals, i.e. to beings who are incapable of exhibiting self-ownership in the sense Kantian rights-theory demands. It has been a conceptual move that, in a very important sense, has helped to humanize us, to redefine the scope of human behaviour, so that the abuse or neglect of such beings are what they appear to be, socially and ideologically centered acts of violence.

While, from the contemporary perspective, it has been necessary to dispense with Kant's notion of individual autonomy, our contemporary understanding of rights (as human rights) has preserved, for the most part, the Kantian-Fichtean rejection of the unilateral character that rights had in the philosophies of Hobbes and Locke (for whom, rights were not thought either to create or to be created by obligations). Rights, Kant, Fichte and Merleau-Ponty would all agree, are created and sustained by "the recognition of man by man." Rights exist, for Kant and Fichte, as reciprocally determinate structures of consciousness. Individuals have rights reciprocally, i.e., only where others have obligations. Where there are rights, there are obligations (in contradistinction to Hobbes); and, where there are no obligations, there are no rights (again, in contradistinction to Hobbes). From a more contemporary perspective, we might say that the rights of the less fortunate obligate us. In fact, one might go so far as to say we have an obligation to feel obligated, since the rights of the less fortunate are dependent on that. Hence, the justice of what Kant referred to as "asserting the right of humanity in your own person," manifesting itself as a form of social and political activism.

Abandonment of the metaphysical baggage-autonomy of will--that Kant and Fichte attached to the concept of rights has diverted our moral attention from autonomy and moral responsibility as preconditions of the possession of rights to needs. Human dignity is no longer measured by one's autonomy, one's ownership of his own actions but, rather, by the material conditions of one's life. Those who lack the means necessary to provide for themselves at a minimum level of decency, we say, have been denied basic human dignity. Conceptually, this leads us to the critical conclusion that this condition, to the extent that it is forced upon people by the competitive structures of an industrialized society, is a subtle, silent act of violence committed upon them. 
Unfortunately, there is a flip side to the contemporary, quasi-Kantian concept of human rights. Shorn of its metaphysical baggage--its demand that people exhibit autonomy of will, self-ownership, and personal responsibility, as preconditions of their capacity to obligate others and, hence, too, of their rights--the Kantian demand that people "assert the right of humanity in their own persons" easily becomes the justification of a naked demand for satisfaction and recognition, with nothing to limit the demand or give it meaning other than the demand itself, augmented, perhaps, by the individual's personal assessment of the material conditions of life he or she needs to have met in order to enjoy basic human dignity. What constitutes the material conditions necessary for human dignity has turned out to be open-ended and highly subjective. Consequently, once the demand for autonomy is removed, there remains no clear-cut criterion for limiting one's assertion of the right of humanity in one's own person other than one's capacity for asserting it. The situation slips easily into something that looks suspiciously like forcing one's will on the other, and becomes the stimulation for (and moral legitimization of) what one might call acts of counter-violence.

Because human rights and human dignity are conceived as having been created and sustained only by recognition and preconditioned by material conditions rather than self-ownership and moral autonomy, it is supremely easy for one to conclude that others have wronged him simply by having more or by having accomplished more and, hence, appear to be worth more. Their possessions and their accomplishments become violations of one's consciousness of equal worth. The other's advantage too easily can be conceived to be undeserved simply because it is an advantage. The demand for recognition and the assertion of the right of humanity in one's own person conceived under these conditions easily translates into a moral legitimization of the violence of those who believe they have been deprived of dignity (i.e. of satisfaction of material conditions). The mutual coercion that worked for Kant [because each owned and was responsible for his own actions] slips easily into the logic of confrontation, where one's open-ended sense of the material conditions needed to maintain a sense of dignity generates one's awareness of one's rights and reciprocal violence. In short, embedded in our concept of human rights is an almost ironic return to the immediacy of Hobbesian natural right 
and of the conceptual content of those structures condemned for their legitimation of structural violence.

Against the backdrop of a critique of the structural violence in contemporary society, we face, in effect, a new form of structural violence, one that remains burdened by many of the same attributes as Hobbesian natural right. The concept of human rights serves as a conceptual enabler, untempered by any considerations of personal responsibility. The act by which one asserts the right of humanity in his own person is logically indistinguishable from the act by which one does violence to another. The structures of violence have not been escaped. This is both complicated and obscured, of course, by the entwined fact that there are many people in the contemporary world who have serious unmet needs, people who live in irreversible conditions of poverty, illiteracy, and ignorance. Unfortunately, there is nothing in the concept that enables us to identify those people in any noncontroversial way.

What is needed, obviously, is a way of conceiving needs, rights and human dignity that is not so open-ended as to justify violence, all in the name of an assertion of the right of humanity in one's own person. In the absence of some such philosophical corrective, we may have to face the fact that the only way to reconcile a system of rights with coexistent freedom and peace is to retum either to the Kantian-Fichtean idea of personal responsibility (and the legitimacy of mutual coercion and retributive punishment that it implied for Kant and Fichte) or to some Hobbesian notion of political authority (with all the possibilities of abuse it appeared to have for Hobbes and Locke).

Loyola University, New Orleans

GARY B. HERBERT 